\title{
The current growth increment of pine tree stands comprising three different age classes
}

\author{
Katarzyna Kaźmierczak ${ }^{\varpi}$ \\ Poznan University of Life Sciences, Faculty of Forestry, Department of Forest Management, sub-department \\ of Forest Mensuration and Forest Yield Science, ul. Wojska Polskiego 71C, 60-325 Poznań, Poland. \\ $\bowtie$ Tel. +4861 8487659, email kkdendro@up.poznan.pl
}

\begin{abstract}
The study presents the results of an analysis of the pine tree growth increments (height increment, dbh increment, basal area increment and volume increment) for a 5-year period. The study involved Scots pine trees of Kraft's class 1, 2 and 3 (dominant stand) in stands of different age classes (II, III, V) growing in fresh mixed coniferous (BMśw) and fresh coniferous (Bśw) forest habitats. The multivariate analysis of variance was performed to assess the statistical significance of age and dominance of trees within a stand on their increment. The dominance position was classified for each tree using Kraft's criteria. The following characteristics were also measured: dbh of the trunk in two directions (N-S and W-E), and crown projection area on the basis of the characteristic tree crown points, projected using of a crown projector, characteristic points in tree crowns ( 7 to 14 on average). The actual height was determined after trees were felled. The following measurements of the single tree growing space were selected and determined: crown projection area $-p_{k}\left(\mathrm{~m}^{2}\right)$, crown diameter $-d_{k}(\mathrm{~m})$, Seebach's growth space number $-d_{k} / d_{1.3}$, crown projection area to basal area ratio $d_{k}^{2} / d_{1.3}^{2}$, crown deflection coefficient $d_{k} / h$, single tree space $p p d=p k \cdot h\left(\mathrm{~m}^{3}\right)$. We assessed the strength of the relationships between tree growth parameters and tree growth space, crown length, relative crown length and slenderness. Both the age and dominance position of trees within the stand affected the growth increments. The strongest correlation among measured traits was between the 5-year volume increment and decreasing slenderness.
\end{abstract}

Key words: height increment, dbh increment, basal area increment, volume increment, growth space, crown, age, biosocial position, Pinus sylvestris

\section{Introduction}

The aim of forest economic practice is to increase total stand volume per area unit. The increase of trees within a stand is determined by many factors. It depends not only on genetic features or habitat quality, but also on the conditions of tree surroundings. In the stand the trees differentiate, achieving different position in vertical stand structure, which determines their increment. Planning and running rational tending interventions can change increasing conditions of trees. It also allows the possibility to change the thickness structure of the stand which leads to obtaining bigger volume increment of good quality trees. The aim of tending interventions is to find an optimum growth space, which will allow us to obtain such a tree increment.

Borowski (1968) claimed that describing a share of biosocial class in stand defines a stand structure and explains its role in current basal area increment. Nevertheless it does not answer the questions of how the structure should be like and trees of which classes to prefer in order to use properly both the habitat production ability and the species characteristics. Predominant trees 
are characterised by a strong basal area increment, but also they occupy a large space. However, trees from a possessed stand from a small growth space obtain a small increment. Borowski (1968) proves that the tree increment decides not only the size of the crown and space occupied, but mainly the biosocial position. The changes in tree increment appear in different life periods in different tempo, therefore it is expedient to deepen and widen the knowledge on tree increment topic.

The aim of this research is the analysis of pines' increment from tree stands aged: 35,50 and 88 years, depending on trees' biosocial position in the dominant stand. Current increments were analysed for: height, breast height diameter, breast height cross section and volume in last 5 -year period. Moreover, the strength of correlation between examined types of pine increments with other measured features and measures of tree growth were estimated.

\section{Material and methods}

The research material was collected on three clear cutting areas, set up in pine stands aged 35, 50 and 88 years in Zielonka Experimental Forest Inspectorate area. The size of the cutting areas was in sequence: 0,10 ha, 0,25 ha and 1,00 ha, and the number of trees growing there (pines) in turn: 302, 274 and 474. The dominant stand on research area in a 35-year old stand consisted of 185 trees, which represented over $61 \%$ of all trees in the stand. In a 50-year old stand it was appropriately 229 which was more than $83 \%$ and in the oldest; aged 88 , nearly $99 \%$ of all trees which is 469 pines. The stands grew typically in pine habitats: 35 - and 88-year old under fresh coniferous forest conditions, third one under fresh mixed coniferous forest conditions.

On standing trees the following were measured:

1) dbh in bark in two directions, N-S and W-E, with an accuracy of $0,1 \mathrm{~cm}$; and the arithmetic mean from those measures was taken as trees' dbh $\left(d_{1,3}\right)$.

2) The area of crown projection $p_{k}\left(\mathrm{~m}^{2}\right)$ based on projected characteristic points of tree crowns (on the average 4 to 14 ).

After cutting down the trees, the following were established (among others):

1) the length of tree with accuracy of $0,01 \mathrm{~m}$ which was accepted as tree's height $(h)$,

2) height increment $(\mathrm{m})$ by whorls for the last 5 years, $I h_{5}$,
3) the height of crown seating - to first living branch of dense crown,

4) the increment of $\mathrm{dbh}(\mathrm{cm})$ for a 5 -year period, $I d_{5}$,

5) the increment in breast height cross section $\left(\mathrm{m}^{2}\right)$ for the last 5-year increment period, $I g_{5}$,

6) current volume increment $\left(\mathrm{m}^{3}\right)$ for the last fiveyear period, $I v_{5}$; specified with sectional method.

For each tree, before cutting down, a biosocial position was established according to Kraft's criteria of classification. The width of crown $d_{\mathrm{k}}$ was obtained from the area of crown projection taken as a circle area. The length of crown $l_{\mathrm{k}}$ was calculated as the difference between the total height of the tree and crown seating height. The measures of growth space of a single tree were specified inter alia: the number of Seebach's growth space $-d_{k} / d_{13}$, crown projection area to basal area ratio $-d_{k}^{2} / d_{1.3}^{2}$, degree of crown spread $-d_{k} / h$, the space of an individual tree $-p p d=p_{k} \times h\left(\mathrm{~m}^{3}\right)$.

In the discussed stands, analyses were made only for a dominant stand (Kraft's classes from I to III). For all the discussed increment features in Kraft's classes only basic statistical characteristics were calculated. The analysis of a variance was made on the bases of tree position in vertical stand structure and its age. It was preceded with the evaluation of compatibility of empirical distribution of all increment features with normal distribution using the KolmogorowSmirnow test. The strength of the correlation between pine increment features with chosen tree features and measures of growth space were calculated. Program 'Statistica 10.1' was used for calculation.

\section{Results}

Basically no departure of empirical distribution of height increment, dbh increment, breast height cross section increment and volume increment was stated from the normal distribution of the examined Kraft's classes in analysed stands (the exception is distribution of dbh in 88-year old trees).

\section{Height increment}

A two-factor variance analysis in reference to a current 5-year height increment showed a statistically essential influence on both the tree position in a stands' structure and trees' age on a diversity of this incremental feature (Table 1). Also a total influence of the biosocial class and age on the size of height increment was stated. 
Table 1. Results of the analysis of variance of a 5 year height increment $\left(I h_{5}\right)$

\begin{tabular}{llrrrrr}
\hline \multicolumn{2}{c}{ Source of variability } & \multicolumn{1}{c}{$S S$} & \multicolumn{1}{c}{$d f$} & \multicolumn{1}{c}{ MS } & \multicolumn{1}{c}{ F } & p-value \\
\hline Intercept & & 1103,132 & 1 & 1103,132 & 24136,88 & 0,000 \\
\hline \multirow{2}{*}{ Main effects } & Kraft's class & 3,306 & 2 & 1,653 & 36,17 & 0,000 \\
& age & 180,949 & 2 & 90,474 & 1979,61 & 0,000 \\
\hline Interactions & Kraft's class $\times$ age & 0,861 & 4 & 0,215 & 4,71 & 0,001 \\
\hline Error & & 39,945 & 874 & 0,046 & & \\
\hline
\end{tabular}

List of abbreviations

$S S$ - sum of squares

$d f$ - degrees of freedom

$M S$ - mean squares

$\mathrm{F}-$ test $\mathrm{F}$

Table 2. Basic statistical characteristics of a 5 year tree increment

\begin{tabular}{|c|c|c|c|c|c|c|c|c|c|c|}
\hline \multirow{3}{*}{ Kraft's class } & \multirow{3}{*}{ Age } & \multirow{3}{*}{$\mathrm{N} / \mathrm{ha}$} & \multicolumn{2}{|c|}{$I h_{5}$} & \multicolumn{2}{|c|}{$I d_{5}$} & \multicolumn{2}{|c|}{$I g_{5}$} & \multicolumn{2}{|c|}{$I v_{5}$} \\
\hline & & & $\bar{x}$ & $s_{d x}$ & $\bar{x}$ & $s_{d x}$ & $\bar{x}$ & $s_{d x}$ & $\bar{x}$ & $s_{d x}$ \\
\hline & & & \multicolumn{2}{|c|}{$\mathrm{m}$} & \multicolumn{2}{|c|}{$\mathrm{cm}$} & \multicolumn{2}{|c|}{$\mathrm{m}^{2}$} & \multicolumn{2}{|c|}{$\mathrm{m}^{3}$} \\
\hline & 35 & 1850 & 1,72 & 0,28 & 0,98 & 0,32 & 0,0017 & 0,0008 & 0,0203 & 0,0104 \\
\hline & 50 & 916 & 1,62 & 0,26 & 1,11 & 0,38 & 0,0029 & 0,0014 & 0,0432 & 0,0210 \\
\hline & 88 & 469 & 0,68 & 0,17 & 0,78 & 0,28 & 0,0030 & 0,0014 & 0,0528 & 0,0235 \\
\hline I & 35 & 330 & 1,89 & 0,32 & 1,38 & 0,23 & 0,0030 & 0,0007 & 0,0374 & 0,0096 \\
\hline I & 50 & 128 & 1,75 & 0,25 & 1,49 & 0,35 & 0,0048 & 0,0013 & 0,0756 & 0,0202 \\
\hline I & 88 & 87 & 0,70 & 0,17 & 0,95 & 0,25 & 0,0045 & 0,0014 & 0,0829 & 0,0219 \\
\hline II & 35 & 650 & 1,79 & 0,24 & 1,08 & 0,21 & 0,0019 & 0,0004 & 0,0219 & 0,0046 \\
\hline II & 50 & 500 & 1,63 & 0,27 & 1,19 & 0,32 & 0,0030 & 0,0010 & 0,0459 & 0,0136 \\
\hline II & 88 & 287 & 0,70 & 0,17 & 0,78 & 0,27 & 0,0030 & 0,0011 & 0,0514 & 0,0163 \\
\hline III & 35 & 870 & 1,61 & 0,23 & 0,76 & 0,23 & 0,0011 & 0,0003 & 0,0127 & 0,0032 \\
\hline III & 50 & 288 & 1,56 & 0,24 & 0,80 & 0,28 & 0,0017 & 0,0006 & 0,0241 & 0,0075 \\
\hline III & 88 & 95 & 0,62 & 0,17 & 0,60 & 0,21 & 0,0019 & 0,0008 & 0,0295 & 0,0097 \\
\hline
\end{tabular}

$I h_{5}-5$ year height increment

$I d_{5}-5$ year dbh increment

$I g_{5}-5$ year basal area increment

$I v_{5}-5$ year volume increment

$\bar{x}$ - arithmetic mean

$s_{d x}-$ standard deviation

With the age of the examined stands, the average height increment diminishes. The difference of height increment is particularly distinct between stands of age 50 and 88 years to the latter's disadvantage. It applies for all Kraft's classes of dominant stand (Table 2). Those results confirm a regularity that the height increment culminates in early age, and after culmination diminishes. Every time the biggest average height increment can be noticed with predominant trees, smaller with dominant trees, and the smallest with co-dominant trees. The differences in height increment between individual Kraft's classes 
were visible in the youngest stand, and in older stands they were smaller (Table 2).

\section{Dbh increment}

Based on the analysis-run of the current dbh increment variance, an essential statistical influence both of tree biosocial position and its age on a diversity of dbh increment was stated (Table 3). The results of variance analysis also confirmed a joint influence of Kraft's class and age on the size of dbh increment. The current dbh increment of trees from Kraft's class 1 was the highest, from next classes it was smaller. The size of this increment depended on age. In the youngest stand it was great, in older it was smaller. The culmination of dbh increment occurred probably already in the pool wood phase. Average dbh increment also depended on tree's age. The highest increment of this feature was found in 50-year old pines. Higher habitat quality had an influence on the obtained result. It regarded all biosocial classes (Table 2). In trees of this age were also observed the greatest differences in $\mathrm{dbh}$ increment between

Table 3. Results of the analysis of variance of a 5 year dbh increment $\left(I d_{5}\right)$

\begin{tabular}{lrrrrrc}
\hline \multicolumn{2}{c}{ Source of variability } & \multicolumn{1}{c}{$S S$} & $d f$ & \multicolumn{1}{c}{$M S$} & \multicolumn{1}{c}{ F } & p-value \\
\hline Intercept & & 600,486 & 1 & 600,486 & 8590,794 & 0,000 \\
\hline \multirow{2}{*}{ Main effects } & Kraft's class & 27,644 & 2 & 13,822 & 197,741 & 0,000 \\
& age & 20,494 & 2 & 10,247 & 146,598 & 0,000 \\
\hline \multirow{2}{*}{ Interactions } & Kraft's class $\times$ age & 2,313 & 4 & 0,578 & 8,274 & 0,000 \\
\hline Error & & 61,092 & 874 & 0,070 & & \\
\hline \hline
\end{tabular}

For symbols see Table 1

Table 4. Results of the analysis of variance of a 5 year basal area increment $\left(I_{5}\right)$

\begin{tabular}{llcrrrc}
\hline \multicolumn{2}{c}{ Source of variability } & \multicolumn{1}{c}{$S S$} & $d f$ & $M S$ & $\mathrm{~F}$ & $p$-value \\
\hline Intercept & & 0,004589 & 1 & 0,004589 & 5089,894 & 0,000 \\
\hline \multirow{2}{*}{ Main effects } & Kraft's class & 0,000550 & 2 & 0,000275 & 304,808 & 0,000 \\
& age & 0,000153 & 2 & 0,000077 & 84,925 & 0,000 \\
\hline \multirow{2}{*}{ Interactions } & Kraft's class $\times$ age & 0,000018 & 4 & 0,000005 & 5,015 & 0,001 \\
\hline Error & & 0,000788 & 874 & 0,000001 & & \\
\hline \hline
\end{tabular}

Table 5. Results of the analysis of variance of a 5 year volume increment $\left(\mathrm{Iv}_{5}\right)$

\begin{tabular}{llccccc}
\hline \multicolumn{2}{c}{ Source of variability } & $S S$ & $d f$ & $M S$ & $\mathrm{~F}$ & $p$-value \\
\hline Intercept & & 1,0707 & 1 & 1,0707 & 5461,890 & 0,000 \\
\hline \multirow{2}{*}{ Main effects } & Kraft's class & 0,1564 & 2 & 0,0782 & 398,966 & 0,000 \\
& age & 0,1033 & 2 & 0,0516 & 263,385 & 0,000 \\
\hline \multirow{2}{*}{ Interactions } & Kraft's class $\times$ age & 0,0145 & 4 & 0,0036 & 18,508 & 0,000 \\
\hline Error & & 0,1713 & 874 & 0,0002 & & \\
\hline \hline
\end{tabular}


Kraft's classes. In the oldest stand, those differences were smaller though still clear. The smallest current dbh increment - in all examined classes of dominant stand - was found in the oldest 88-year old pines (Table 2).

\section{Breast height cross section increment}

The variance analysis-run in reference to the current breast height cross section increment, showed an essential statistical influence on both the biosocial position of a tree in a stand and the age on a size of this increment (Table 4). Also a joint influence of biosocial class and age on the size of this type of increment was stated.

The average breast height cross section increment depended on age and Kraft's classes. In case of codominant trees it was the biggest in the oldest stand, and in dominant trees it increased to age 50, and then remained on the same level. Average increment of predominant trees was formed differently. The highest average breast height cross section increment was found in a 50-year old stand, later a slight diminish of this incremental feature was visible (Table 2). In trees of this age, highest differences in dbh increment between the discussed Kraft's classes were also observed. This confirms better habitat conditions for this stand's growth.

\section{Volume increment}

Also the results of variance analysis of current volume increment showed an essential statistical influence of the biosocial tree position and age on this feature's diversity (Table 5). Moreover a joint influence

Table 6. Coefficient of linear correlation between tree increments and chosen traits

\begin{tabular}{|c|c|c|c|c|c|c|c|c|c|c|c|c|}
\hline Trait & $\begin{array}{c}\text { Kraft's } \\
\text { class }\end{array}$ & $d_{1,3}$ & $h$ & $p_{k}$ & $d_{k}$ & $d_{k} / d_{1,3}$ & $d_{k}^{2} / d_{1.3}^{2}$ & $p p d$ & $d_{k} / h$ & $l_{k}$ & $l_{k} / h$ & $h / d_{1,3}$ \\
\hline \multicolumn{13}{|c|}{35 year-old stand } \\
\hline$I h_{5}$ & $-0,406^{*}$ & $0,313^{*}$ & $0,555^{*}$ & $0,311^{*}$ & $0,304^{*}$ & 0,059 & 0,047 & $0,363^{*}$ & $0,153^{*}$ & $0,510^{*}$ & $0,412^{*}$ & $-0,130$ \\
\hline$I d_{5}$ & $-0,726^{*}$ & $0,672 *$ & $0,627^{*}$ & $0,620^{*}$ & $0,628^{*}$ & 0,118 & 0,101 & $0,657^{*}$ & $0,487^{*}$ & $0,596^{*}$ & $0,484^{*}$ & $-0,554^{*}$ \\
\hline$I g_{5}$ & $-0,830^{*}$ & $0,864^{*}$ & $0,741^{*}$ & $0,700^{*}$ & $0,691^{*}$ & $-0,006$ & $-0,021$ & $0,753^{*}$ & $0,514 *$ & $0,697^{*}$ & $0,554 *$ & $-0,727 *$ \\
\hline$I v_{5}$ & $-0,852^{*}$ & $0,909^{*}$ & $0,789^{*}$ & $0,703 *$ & $0,687^{*}$ & $-0,059$ & $-0,075$ & $0,764^{*}$ & $0,493 *$ & $0,734^{*}$ & $0,577^{*}$ & $-0,750^{*}$ \\
\hline \multicolumn{13}{|c|}{50 year-old stand } \\
\hline$I h_{5}$ & $-0,231^{*}$ & $0,185^{*}$ & $0,418^{*}$ & 0,071 & 0,068 & $-0,079$ & $-0,091$ & 0,115 & $-0,031$ & $0,372 *$ & $0,288^{*}$ & $-0,043$ \\
\hline$I d_{5}$ & $-0,599 *$ & $0,654^{*}$ & $0,571^{*}$ & $0,546^{*}$ & $0,546^{*}$ & $0,142 *$ & 0,129 & $0,574 *$ & $0,448^{*}$ & $0,532 *$ & $0,418^{*}$ & $-0,588^{*}$ \\
\hline$I g_{5}$ & $-0,721^{*}$ & $0,837^{*}$ & $0,681^{*}$ & $0,677^{*}$ & $0,664^{*}$ & 0,124 & 0,102 & $0,718^{*}$ & $0,540^{*}$ & $0,620^{*}$ & $0,475^{*}$ & $-0,742 *$ \\
\hline$I v_{5}$ & $-0,772 *$ & $0,856^{*}$ & $0,767^{*}$ & $0,715^{*}$ & $0,697 *$ & $0,147^{*}$ & 0,124 & $0,765^{*}$ & $0,554^{*}$ & $0,648^{*}$ & $0,476^{*}$ & $-0,726^{*}$ \\
\hline \multicolumn{13}{|c|}{88 year-old stand } \\
\hline$I h_{5}$ & $-0,148^{*}$ & $0,121 *$ & $0,352^{*}$ & $0,113^{*}$ & $0,122^{*}$ & 0,055 & 0,050 & $0,150^{*}$ & 0,021 & $0,160^{*}$ & 0,067 & 0,025 \\
\hline$I d_{5}$ & $-0,396^{*}$ & $0,332 *$ & $0,337^{*}$ & $0,383^{*}$ & $0,391 *$ & $0,213^{*}$ & $0,201 *$ & $0,400^{*}$ & $0,319^{*}$ & $0,326^{*}$ & $0,272^{*}$ & $-0,248^{*}$ \\
\hline$I g_{5}$ & $-0,606^{*}$ & $0,660^{*}$ & $0,521^{*}$ & $0,594 *$ & $0,594 *$ & $0,172 *$ & $0,154^{*}$ & $0,627^{*}$ & $0,475^{*}$ & $0,501 *$ & $0,408^{*}$ & $-0,542^{*}$ \\
\hline$I v_{5}$ & $-0,706^{*}$ & $0,806^{*}$ & $0,640^{*}$ & $0,683^{*}$ & $0,684^{*}$ & $0,153^{*}$ & $0,134^{*}$ & $0,727^{*}$ & $0,534 *$ & $0,568^{*}$ & $0,443^{*}$ & $-0,661^{*}$ \\
\hline
\end{tabular}

* coefficient of correlation significant at level 0,05

$p_{k}-$ crown projection area

$d_{k}$ - crown diameter

$d_{k} / d_{1,3}-$ Seebach's growth space number

$d_{k}^{2} / d_{1,3}^{2}-$ crown projection area to basal area ratio

ppd-single tree space

$d_{k} / h-$ crown spread

$l_{k}-$ crown lenght

$l_{k} / h$ - relative crown lenght

$h / d_{1,3}-$ slenderness coefficient. 
of biosocial class and age on a size of basal area increment was stated.

The average volume increment grew with the age of the examined stands. It was visible in all biosocial classes (Table 2). The highest values of the volume increment were found in predominant trees. With age, the differences of the basal area increment between trees of different biosocial position increased.

\section{Increment versus Kraft's classes and tree features}

A power of relation was examined between particular types of increments and Kraft's class; the pine measure features the dbh and height, chosen measures of space, growth of a single tree (area of crown projection, width of crown, the number of Seebach's space growth, crown projection area to basal area ratio, the degree of crown inclination), the total and relative length of crown, and trees slenderness. The analysis was run for a dominant layer in each of the examined stands. The results are shown in Table 6 . On the basis of the analysis it can be stated that with the deterioration of trees' position all types of examined increments diminish. The strongest relation with biosocial class was found in the current volume increment, slightly weaker - current breast height cross section increment, weaker - current dbh increment, and the weakest - current height increment. This order was stated in all examined stands, however, with stands age the increment correlation factor with biosocial class reached lower values (Table 6).

Similar order of correlation power was observed in the case of relation of pine increments with measure features, i.e. dbh and height. In each of the stands with current height increment, stronger than the other incremental features, a height of tree is connected, and with age the strength of this correlation weakens. Remaining incremental features are characterised with a higher correlation power with dbh than with height, and the power of correlation also weakens with age.

The chosen measures of a single tree space growth to a different degree influence the examined types of pine increments. For pines the strongest relation with increment show a space of a single tree (Table 6). The weakest influence on height increment, relevant only with the youngest stand, has a degree of crown inclination. Among measures of a single tree space growth a weak influence on examined types of increments - in most cases the correlation factor was statistically irrelevant - two features distinguish themselves - the number of Seebach's space growth and crown projection area to basal area ratio. After assessing the power of relation of incremental features with a crown length and its relative length, each time was stated to stronger the relation with a crown length. The relation with volume increment and breast height cross section increment was strong. In addition, with the stand's age the power of correlation diminished, and in the oldest stand (88-year old) the relation of relative crown length with height increment was irrelevant (Table 6).

The last feature examined, which influences pines' increment, was the tree's slenderness $\left(h / d_{1,3}\right)$. A relevant relation between slenderness and height increment was not stated. Moreover, it turned out that with the increase of slenderness factor, the diminishment of incremental features was related. With age, the power of correlation was clearly seen to have weakened.

\section{Discussion}

The analysis showed that the size of pines' increments substantially influences tree's biosocial position in stand's vertical structure. With the lowering of trees' biosocial position, all examined increments diminished. Retrospective analysis of growth and increment of 50 -year old pines taken by Lemke (1972), showed that curves of trees' current volume increment of individual Kraft's classes were formed in the biosocial class order. Similar results were achieved by Zajączkowski (1973) in reference to pine from the dominant stand layer. Analogous result was obtained by Šmelko (1982) in reference to beech and spruce. Żółciak (1963), by analysing formation of pines' increments in different life periods, stated that trees by changing temporarily their position in stand, on average maintain their permanent location.

According to the obtained results, Borowski (1968) stated that trees' increment decides not only the size of crown and taken space, but also a biosocial position; it was clearly visible in a younger stand with the average age of 44 years. The volume increment per square metre of crown projection area diminishes with the growth of crown projection space in each biosocial class. With small crown projection area it diminishes quickly, and with great projection area the lapse happens slower. With the same crown projection area, the bigger the volume increment is the bigger and higher the tree's position in vertical stand's structure is. The size of tree's volume increment under given conditions is determined by the size of assimilation apparatus and biosocial position. 
The most economic is increment of trees, which occupy a high biosocial position with a low crown projection area.

Zajączkowski (1973) revealed the increase of volume increment with a growth of crown projection area in biosocial classes. Trees of higher Kraft's classes were characterised with a higher volume increment than trees from lower classes with crowns of similar sizes.

The presented research showed the influence of height space (defined by a crown size) on different increment types. The size of crown was essentially related with quantity of assimilation apparatus found in crown. Lemke (1968), defying the relation between crown size and trees' increments in stands, presented relevant relation between crown elements and different types of increments. He took into account the crown volume (as the volume of a cylinder of crowns' width and length), the area of crown projection and its length. The relation between crown measure elements and individual increments form in the same way in both increment periods, although in longer increase period they were slightly stronger.

Lemke (1966) revealed the influence of size of assimilation apparatus on trees' volume increment. The relation between the crown size and the trees' increment can be described most precisely by the volume of leafy branches. The author also stated that when estimating the influence of assimilation apparatus or the crown size on trees' increments, one shall not use the results only for a certain biosocial class, because it may lead to incorrect conclusions. He also revealed that the production of wood mass per assimilation apparatus unit in the predominant trees' class was $1 / 3 \mathrm{rd}$, and in class of dominant trees $1 / 7$ th lower than that in class of codominant trees. He stated that in the Kraft's class 3, the trees with small crowns are characterised with a higher productivity than trees with big crowns. The smallest assimilation energy had trees with the smallest crowns (basically dominant trees), although average basal area increment of trees from class 1 was closely three times bigger than trees from class 3. Despite smaller assimilation energy, trees with big crowns produce the largest wood mass (Lemke 1966).

Dudek (1969) showed that younger trees with similar crown projection area have bigger dbh increment and bigger basal area increment per dbh cross-sectional area unit (higher factor of volume increment intensity) than older trees.

Svensson's (1998) research, run on a material rich in mean sample trees in reference to pine and spruce, showed the necessity of taking into consideration crown features (relative crown length) when defying basal area increment.

Skrzyszewski (1995) in 11 spruce stands among the examined 15 , showed the relation of crown length with current 10-year old increment in breast height cross section. Relative length of the crown influenced in an essential statistical way on this kind of tree increment was seen in 9 stands out of 15 . The relation of mentioned features was also stated by the author in the case of larch. The increase in breast height cross section was with the essentially combined length and width of crown in 6 stands from examined 7 and relative length of crown in 4 stands from 6 examined. The relation between those features was stronger with larch than with spruce (Skrzyszewski 1995).

Jaworski and others $(1988,1995)$ showed that correlation factor between the relative crown length and increment of annual ring in younger stands was 0,579 , and in older was 0,515 .

The research by Kaźmierczak and others (2008) showed the influence of slenderness on dbh increment and volume increment. It was stated that with the increase in breast height cross section increment, the slenderness of trees diminished.

\section{Conclusions}

1) Biosocial position occupied by a tree, significantly differentiates a size of pines' incremental features of the examined stands. With the decreasing of biosocial position all examined increments diminish.

2) The size of incremental features is determined also by a tree's age.

3) With tree's biosocial position in stand (Kraft's classes) the strongest relation is connected to a current volume increment and least to height increment. With age, the power of correlation weakens.

4) The relations of increments between pine's dbh and height are characterised by a similar correlation power.

5) The measures of a single tree growth space influence to a various degree on a size of pines increments. A single tree space shows the strongest relations with volume increments.

6) The number of Seebach's growth space and quotient of crown projection area are characterised in most cases by insignificant correlation with pine's increments. 
7) The length and relative length of crown influences on pines increments size (the strongest relation with current volume increment).

8) The increase of slenderness factor causes a reduction of incremental features (strong relation of slenderness with volume increment).

\section{References}

Borowski M. 1968. Udział klas biosocjalnych w przyroście drzewostanu sosnowego. Folia Forestalia Polonica, Seria A, 19: 117-134.

Dudek A. 1969. Zależność intensywności przyrostu miąższości i przyrostu pierśnicy od wielkości korony. Folia Forestalia Polonica, Seria A, z. 15: 149-169.

Jaworski A., Kaczmarski J., Pach M., Skrzyszewski J., Szar J. 1995. Ocena żywotności drzewostanów jodłowych w oparciu o cechy biomorfologiczne koron i przyrost promienia pierśnicy. Acta Agraria et Silvestria, Series Silvestris, 33: 115-131.

Jaworski A., Podlaski R., Sajkiewicz P. 1988. Kształtowanie się zależności między żywotnością i cechami biomorfologicznymi korony a szerokością słojów rocznych u jodeł. Acta Agraria et Silvestria, Series Silvestris, 27: 63-84.

Kaźmierczak K., Pazdrowski W., Mańka K., Szymański M., Nawrot M. 2008. Kształtowanie się smukłości pni dębu szypułkowego (Quercus robur L.) w zależności od wieku drzew. Sylwan, 7: 39-45.
Lemke J. 1966. Korona jako kryterium oceny dynamiki wzrostowej drzew w drzewostanie sosnowym. Folia Forestalia Polonica, Seria A, 12: 185-236.

Lemke J. 1968. Związek pomiędzy wielkością korony a przyrostem drzew w drzewostanach sosnowych. Prace Komisji Nauk Rolniczych i Komisji Nauk Leśnych PTPN, 25: 43-90.

Lemke J. 1972. Retrospektywna analiza wzrostu i przyrostu drzew w 50-letnim drzewostanie sosnowym. Folia Forestalia Polonica, Seria A, 19: 5-23.

Skrzyszewski J. 1995. Charakterystyka przyrostowa oraz kształtowanie się zależności pomiędzy wybranymi cechami drzew a przyrostem promienia na pierśnicy świerka i modrzewia. Acta Agraria et Silvestria, Series Silvestris, 33: 141-158.

Svensson S.A. 1998. Estimation of annual stem volume increment. SUAS, Dept. of Forest Survey Report 46, Umea.

Šmelko S. 1982. Biometrickie zakonitosti rastu a prirastku lesnych stromov a porastov. Bratislava, Veda.

Zajączkowski J. 1973. Przyrost miąższości w klasach biosocjalnych starszych drzewostanów sosnowych. Sylwan, 1: 1-9.

Żółciak E. 1963. Analiza kształtowania się przyrostów drzew w różnych okresach życia drzewostanów sosnowych w borze świeżym na przykładzie Nadleśnictwa Doświadczalnego WSR Zielonka. Roczniki WSR w Poznaniu, 14: 249-293. 